\title{
Antibacterial Activity Test of Ethanol Extract of Mangkokan Leaves (Polyscias scutallarium (Burm.f.) Fosberg) against Escherichia coli and Staphylococcus aureus
}

\section{Uii Aktivitas Antibakteri Ekstrak Etanol Daun Mangkokan (Polyscias scutallarium (Burm.f.) Fosberg) terhadap Bakteri Escherichia coli dan Staphylococcus aureus}

\author{
Deri Islami ${ }^{1}$, Vonny Kurnia Utama ${ }^{2}$, Dian Mayasari ${ }^{3}$, Yan Hendrika ${ }^{4}$ \\ 1,2,3,4 Fakultas Farmasi dan Ilmu Kesehatan, Universitas Abdurrab, Pekanbaru, Indonesia \\ E-mail: deri.islami@univrab.ac.id
}

Article Info
Article history
Received date: 2022-01-06
Revised date: 2022-01-26
Accepted date: $2022-01-27$

\begin{abstract}
Mangkokan is one of traditional medicinal plants that has many benefits in restoring health, such as preventing hair loss, treating wounds, antibacterial agent, improving blood circulation and as an antioxidant agent. This study aimed to examine the activity of the ethanol extract of the mangkokan leaf (Polyscias scutellarium (Burm.f.) Fosberg) against Escherichia coli and Staphylococcus aureus. The extraction process was carried out by gradual maceration through three solvents including $n$-hexane, ethyl acetate, and ethanol. The antibacterial activity test was carried out by agar diffusion method by calculating diameter of the inhibition zone from ethanol extract of mangkokan leaf with four variation concentrations: $20 \%, 40 \%, 60 \%$, and $80 \%$. The antibacterial activity of the ethanolic extract of the mangkokan leaf against Escherichia coli resulted in the average diameter od the inhibition zone at the following concentrations: $20 \%(5,9 \mathrm{~mm}), 40 \%(5,2 \mathrm{~mm}), 60 \%(5,9$ $\mathrm{mm})$, dan $80 \%(7,03 \mathrm{~mm}$. While antibacterial test against Staphylococcus aures resulted in the average diameter of the inhibition zone at the following concentrations: $20 \%(9,66 \mathrm{~mm}), 40 \%(10,71 \mathrm{~mm}), 60 \%(11,27 \mathrm{~mm}), 80 \%$ $(12,42 \mathrm{~mm})$.
\end{abstract}

Keywords:

Antibacterial; Ethanol extract; Mangkokan leaf

\begin{abstract}
Abstrak
Tanaman mangkokan ialah salah satu tanaman obat tradisional yang banyak dimanfaatkan dalam pemulihan kesehatan, diantaranya untuk mencegah rambut rontok, mengobati luka, antibakteri, memperlancar peredaran darah dan sebagai antioksidan tubuh. Penelitian ini bertujuan untuk uji aktivitas ekstrak etanol daun mangkokan (Polyscias scutellarium (Burm.f.) Fosberg) terhadap bakteri Escherichia coli dan Staphylococcus aureus. Proses ekstraksi daun mangkokan dilakukan dengan maserasi bertingkat yang menggunakan 3 pelarut yaitu, n-heksana, etil asetat dan etanol. Pengujian antibakteri dilakukan dengan metode difusi agar dengan menghitung diameter zona hambat dari ekstrak etanol daun mangkokan terhadap bakteri Escherichia coli dan Staphylococcus aureus. Uji aktivitas antibakteri ekstrak etanol daun mangkokan dilakukan dengan 4 konsentrasi yaitu: 20\%, 40\%, 60\%, dan 80\%. Aktivitas antibakteri dari ekstrak etanol daun mangkokan terhadap bakteri Escherichia coli menghasilkan rata-rata diameter zona hambat pada konsentrasi berikut secara berturut-turut: $20 \%(5,9 \mathrm{~mm}), 40 \%(5,2 \mathrm{~mm}), 60 \%(5,9 \mathrm{~mm})$, dan $80 \%(7,03 \mathrm{~mm})$. Sedangkan penguijan terhadap bakteri Staphylococcus aureus menghasilkan rata-rata diameter zona hambat pada konsentrasi secara
\end{abstract}




\section{PENDAHULUAN}

Pemanfaatan tanaman obat sebagai obat tradisional telah lama dikenal oleh masyarakat Indonesia sejak zaman dahulu. Obat tradisional juga lebih mudah didapatkan dan tersedia di lingkungan sekitar. Walaupun demikian, penelitian lebih lanjut terkait penggunaan tanaman tradisional sebagai obat diperlukan untuk pembuktian secara saintifik terkait keamanan dan toksisitasnya [1]. Hal ini dimaksudkan agar penggunaan obat secara tradisional dapat dipertanggungjawabkan dengan dibuktikan secara ilmiah mengenai zat aktif dari tanaman atau tumbuhan tersebut [2].

Tanaman mangkokan (Polyscias scutellarium (Burm.f.) sering digunakan sebagai tanaman hias dan biasanya dijadikan tanaman pagar bagi masyarakat. Tanaman mangkokan dimanfaatkan secara tradisional untuk mencegah rambut rontok, mengobati luka, antibakteri, memperlancar peredaran darah dan antioksidan tubuh. Secara turun temurun daun mangkokan telah digunakan oleh wanita pedesaan untuk melindungi kulit dari paparan sinar matahari, mereka mencampurkan daun mangkokan dengan bedak dingin kemudian dioleskan ke wajah sebelum beraktivitas di luar rumah [3].

Kandungan mentabolit sekunder dari Daun mangkokan ialah flavonoid, alkaloid, dan saponin (Flavonoid pada tanaman mangkokan memiliki aktivitas biologis sebagai antibakteri, antioksidan dan anti serangga [4]. Senyawa fenol memiliki sifat koagulator protein yang dapat berperan sebagai agen antibakteri, sedangkan senyawa fenol akan membentuk senyawa kompleks dengan protein ekstraseluler.
Hal ini dapat menyebabkan gangguan pada integritas membran sel bakteri sehingga dapat menghambat pertumbuhan bakteri [5].

Bakteri Escherichia coli merupakan salah satu spesies utama bakteri Gram negatif berbentuk batang dan pendek (kokobasil), berukuran 0,4-0,7 $\mu \mathrm{m} \times 1,4 \mu \mathrm{m}$. Bakteri ini dapat menjadi patogen apabila jumlahnya meningkat dalam saluran pencernaan atau berada di luar usus. Escherichia coli biasanya dapat tumbuh baik pada hampir pada semua media pembenihan [6]. Bakteri Staphylococcus aureus tergolong pada bakteri Gram positif berbentuk bulat yang memiliki berdiameter 0,7-1,2 $\mu \mathrm{m}$. Suhu optimum untuk tumbu dari bakteri ini ialah $37^{\circ} \mathrm{C}$, tetapi membentuk pigmen paling baik pada suhu kamar sekitar suhu $20-25^{\circ} \mathrm{C}$. Lebih dari $90 \%$ isolat klinik menghasilkan Staphylococcus aureus yang mempunyai kapsul polisakarida atau selaput tipis yang berperan dalam virulensi bakteri [7].

\section{METODE}

\section{Bahan:}

Sampel (daun mangkokan), aquades, media Mueller Hinton Agar (MHA), pelarut DMSO (Dimetil Sulfoksida), n-heksana $\left(\mathrm{C}_{6} \mathrm{H}_{14}\right)$, Etil asetat $\left(\mathrm{C}_{4} \mathrm{H}_{8} \mathrm{O}_{2}\right)$, Etanol $96 \% \quad\left(\mathrm{C}_{2} \mathrm{H}_{5} \mathrm{OH}\right)$, kontrol positif (Ciprofloxacin), Blank disk, $\mathrm{NaCl}$ fisiologis, $\mathrm{H}_{2} \mathrm{SO}_{4}, \mathrm{BaCl}_{2} .2 \mathrm{H}_{2} \mathrm{O}$.

Alat:

Alumunium foil, erlenmeyer, pinset, bunsen, mikropipet, autoklaf, timbangan analitik, waterbath, rotary vacuum, beaker glass, tabung reaksi, cawan petri, incubator, kawat ose, jangka sorong, destilasi, laminar air flow (LAF). 


\section{Persiapan sampel:}

Sampel yang digunakan pada penelitian ini adalah daun mangkokan (Polyscias scutallarium (Burm.f.)Fosberg) yang sudah tua yang diambil di daerah Pandau Pekanbaru.

\section{Ekstraksi Daun Mangkokan (Polyscias} scutallarium (Burm.f.)Fosberg).

Pada penelitian ini, proses ekstraksi dilakukan dengan metode maserasi dengan 2 kali pengulangan dengan pelarut $n$ heksana, etil asetat, dan etanol. Metode maserasi dilakukan dengan cara merendam sebanyak $2 \mathrm{~kg}$ daun mangkokan dengan pelarut $n$-heksana di dalam botol gelap selama 2 hari sambil sesekali diaduk. Setelah proses maserasi selesai, dilakukan penyaringan sari $n$-heksana menggunakan kapas. Ampas hasil penyaringan dikeluarkan dari botol dan dikeringkan selama setengah jam, lalu ampas dimasukan kembali kedalam botol gelap. Proses maserasi dilanjutkan dengan pelarut etil asetat selama 3 hari kemudian dilakukan penyaringan. Proses maserasi dengan pelarut etil asetat ini dilakukan sebanyak 2 kali pengulangan.

Ampas dari proses maserasi etil asetat dikeluarkan dari botol dan dikeringkan kemudian ampas dimasukkan kembali dalam botol gelap dan direndam dengan etanol $96 \%$ selama 2 hari dan diulang selama 2 pengulangan. Larutan maserat dari fraksi $n$ heksan, etil asetat, dan etanol dipekatkan dengan alat rotary evaporator hingga diperoleh ekstrak kental.

Persentase rendemen dari ekstrak dapat dihitung dengan rumusan sebagai :

$\%$ Rendemen ekstrak = $\frac{\text { bobot ekstrak kental yang diperoleh }(\mathrm{g})}{\text { bobot simplisia yang diekstrak (g) }} X 100 \%$

\section{Uii aktivitas antibakteri}

Suspensi Escherichia coli dioleskan pada permukaan media secara zigzag menggunakan kapas lidi steril, sampai semua bagian media rata terinokulasi. Kemudian cakram blank disk diletakkan pada permukaan media dan diteteskan ekstrak etanol daun mangkokan dengan konsentrasi $20 \%, 40 \%, 60 \%, 80 \%$ dengan diberi tekanan. Cakram disk Ciprofloxacin diletakkan dibagian atas cawan petri. Pengulangan dilakukan sebanyak 3 kali kemudian di inkubasi selama $1 \times 24$ jam pada suhu $37^{\circ} \mathrm{C}$ dan diukur zona bening yang terbentuk disekitar disk.

\section{HASIL DAN PEMBAHASAN}

\section{Persiapan Sampel}

Pada penelitian ini menggunakan sampel daun mangkokan yang sudah tua dan berwarna hijau pekat (tua). Daun mangkokan sudah tua digunakan karena metabolit sekunder di dalam daun mangkokan tersebut lebih banyak dibanding dengan daun mangkokan yang masih muda. Sampel segar yang digunakan ialah sebanyak $2 \mathrm{~kg}$, sampel ini didapatkan dipekanbaru di daerah pandau.

Pada pembuatan simplisia, daun mangkokan dicuci bersih dengan air mengalir agar menghilangkan kotoran atau debu. Proses selanjutnya adalah sortasi basah dimana daun mangkokan yang sudah tidak bagus dibuang. Sampel yang sudah disortasi basah dilakukan perajangan tipis-tipis. Tujuan dari proses perajangan ini untuk memperluas permukaan simplisia sehingga mempercepat proses pengeringan simplisia. Pada proses pengeringan bertujuan agar sampel dapat disimpan dalam waktu yang lama dengan cara mengurangi kadar air dilakukan dengan cara dikeringkan pada suhu ruangan $25-27^{\circ} \mathrm{C}$. Setelah simplisia kering dilanjutkan proses sortasi kering. Tujuan dari proses sortasi kering untuk memisahkan kotoran dan simplisia yang rusak karena proses sebelumnya. Kemudian simplisia yang sudah kering dihaluskan sampai menjadi menjadi serbuk $[8 ; 9]$. Hasil serbuk simplisia yang diperoleh ialah sebanyak $2 \mathrm{~kg}$. 


\section{Uii aktivitas antibakteri}

Hasil dari uji aktivitas antibakteri yang telah dilakukan menggunakan bakteri Escherichia coli menunjukkan rata-rata diameter zona hambat secara berturut-turut pada konsentrasi $20 \%(5,9 \mathrm{~mm}), 40 \%(5,2 \mathrm{~mm})$, $60 \%(5,9 \mathrm{~mm}), 80 \%(7,03 \mathrm{~mm})$, kontrol positif $(23,8 \mathrm{~mm})$. Rata-rata diameter zona hambat paling besar terdapat pada konsentrasi $80 \%$ yaitu $7,03 \mathrm{~mm}$, dan ratarata diameter zona hambat paling rendah terdapat pada konsentrasi $40 \%$ yaitu 5,2 $\mathrm{mm}$. Sedangkan bakteri Staphylococcus aureus menunjukkan rata-rata diameter zona hambat berturut-turut pada konsentrasi $20 \%$ $(9,66 \mathrm{~mm}), 40 \%(10,71 \mathrm{~mm}), 60 \%(11,27$ $\mathrm{mm}), 80 \%(12,42 \mathrm{~mm}), 100 \%(11,99 \mathrm{~mm})$, kontrol positif $(25,03 \mathrm{~mm})$. Rata-rata diameter zona hambat paling besar terdapat pada konsentrasi $80 \%$ yaitu 12,42 $\mathrm{mm}$, dan rata-rata diameter zona hambat paling rendah terdapat pada konsentrasi $20 \%$ yaitu $9,66 \mathrm{~mm}$. Aktivitas antibakteri ini tergolong dalam respon hambat yang kuat pada konsentrasi $60 \%, 80 \%$, dan $100 \%$, sedangkan untuk konsentrasi 20\%, 40\% memiliki respon hambat yang lemah.

Sifat aktivitas antibakteri ditentukan berdasarkan diameter zona hambat. Suatu antibakteri dikatakan mempunyai aktivitas terhadap bakteri, bila memberikan nilai zona hambat dengan ukuran 6-10 mm dikategorikan lemah, 11-20 mm dikategorikan kuat, dan 21-30 mm atau lebih dikategorikan sangat kuat [10].

Tabel 2. Uji aktivitas antibakteri dari ekstrak Etanol

\begin{tabular}{lcc}
\hline Konsentrasi & \multicolumn{2}{c}{ Diameter zona bening $(\mathbf{m m})$} \\
$(\mu \mathrm{g} /$ disk) & Escherichia coli & $\begin{array}{c}\text { Staphylococcus } \\
\text { aureus }\end{array}$ \\
& &
\end{tabular}

\begin{tabular}{lcc}
\hline $\begin{array}{l}\text { Ekstrak } \\
\text { etanol }\end{array}$ & \\
$20 \%$ & $5,9 \mathrm{~mm}$ & $9,66 \mathrm{~mm}$ \\
$40 \%$ & $5,2 \mathrm{~mm}$ & $10,71 \mathrm{~mm}$ \\
$60 \%$ & $5,9 \mathrm{~mm}$ & $11,27 \mathrm{~mm}$ \\
$80 \%$ & $7,03 \mathrm{~mm}$ & $12,41 \mathrm{~mm}$ \\
Ciprofloxacin & $23,8 \mathrm{~mm}$ & $25,03 \mathrm{~mm}$ \\
\hline
\end{tabular}

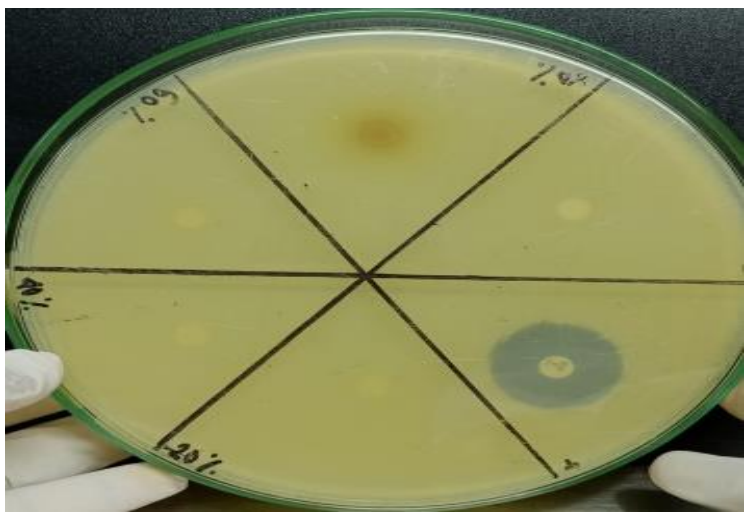

(a)

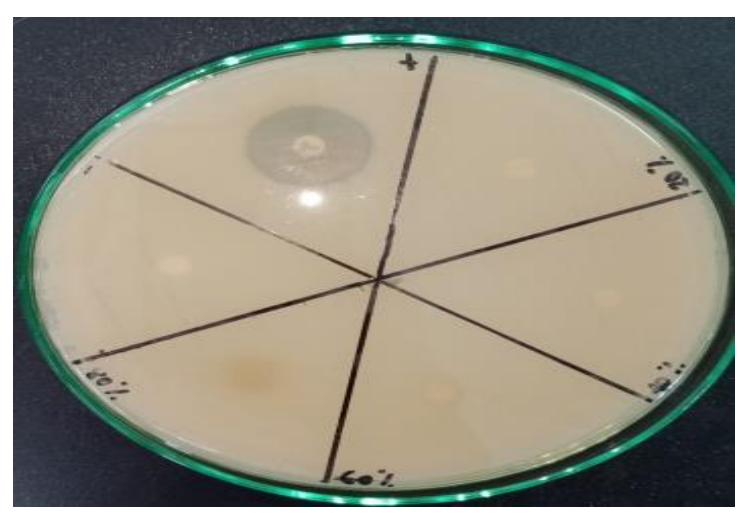

(b)

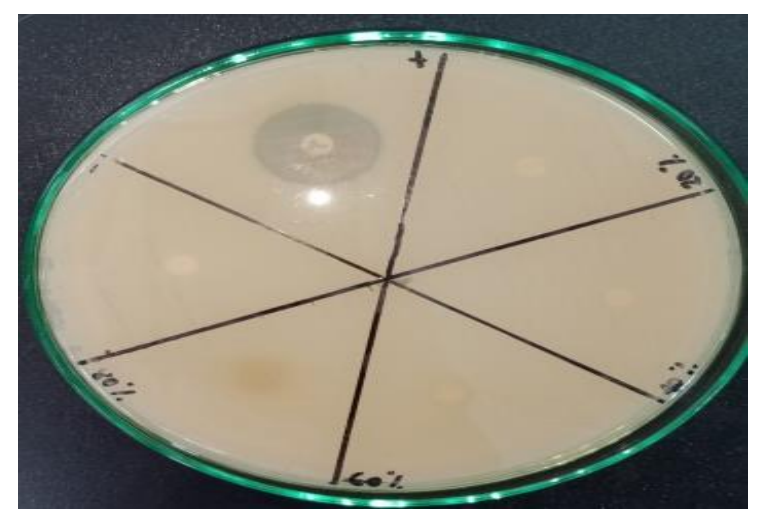

(c)

Gambar 1. cawan petri terhadap bakteri escherichia coli (a) pengulangan 1 (b) pengulangan 2 (c) pengulangan 3 


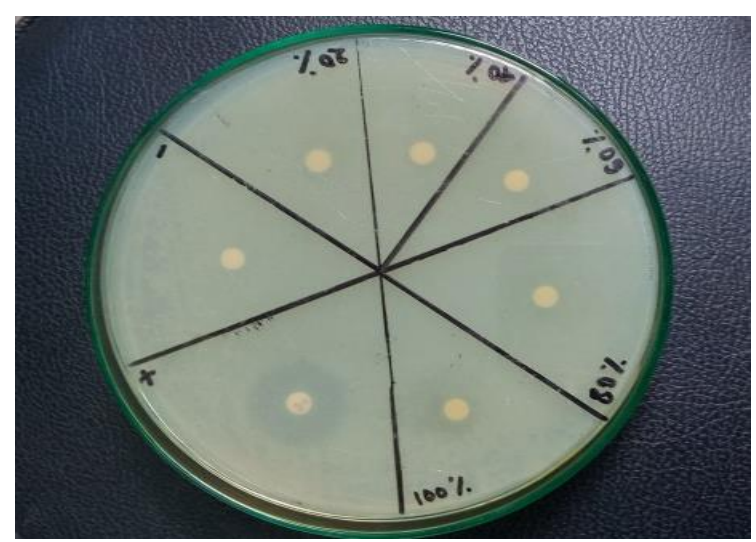

(a)

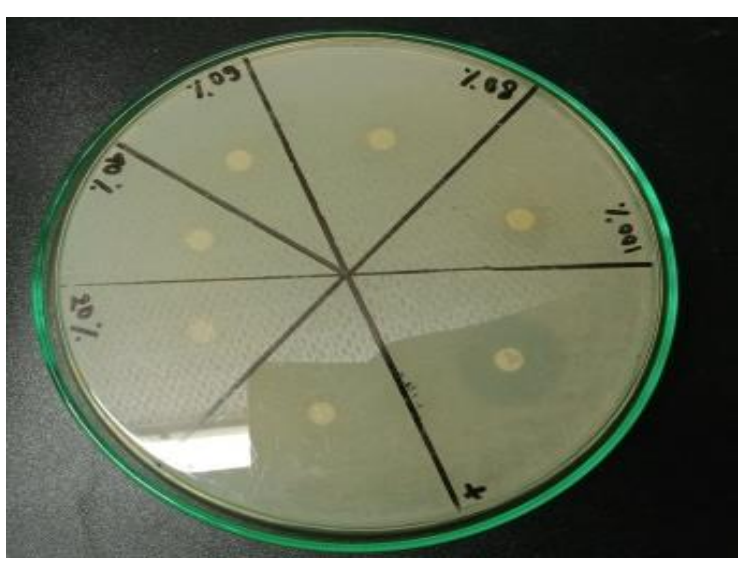

(b)

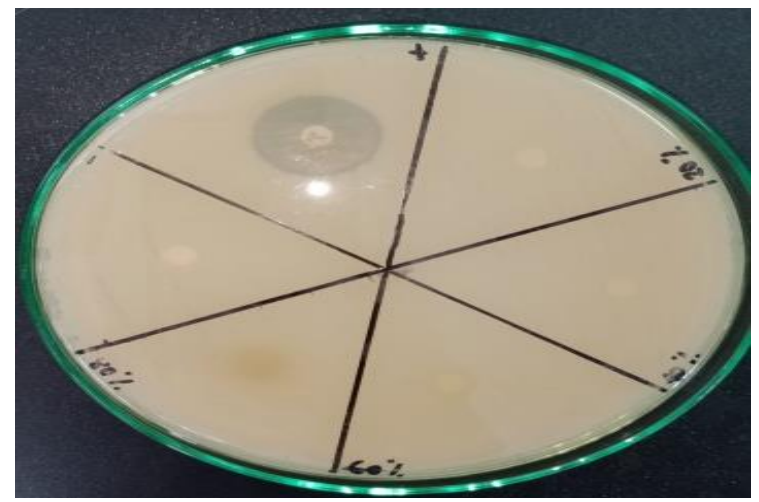

(c)

Gambar 2. cawan petri terhadap bakteri Staphylococcus aureus (a) pengulangan 1 (b) pengulangan 2 (c) pengulangan 3

\section{SIMPULAN}

Berdasarkan dari hasil penelitian yang telah dilakukan, ekstrak etanol daun mangkokan (Polyscias scutallarium (Burm.f.) Fosberg) memiliki aktivitas antibakteri yang tergolong dalam respon hambat sedang terhadap bakteri Escherichia coli. Sedangkan pada bakteri Staphylococcus aureus memiliki aktivitas antibakteri yang tergolong dalam respon hambat kuat pada konsentrasi $60 \%$, $80 \%$, dan $100 \%$ dan tergolong dalam respon hambat lemah pada konsentrasi $20 \%$, dan $40 \%$.

\section{DAFTAR PUSTAKA}

[1] S.B Hyeronimus, Ragam dan Khasiat Tanaman Obat, 1st ed, Jakarta: Agro Media, 2008

[2] S. Dalimartha, Atlas Tumbuhan Obat Indonesia, Jilid 1, Trubus: Jakarta Agriwijaya: 86-89, 1999

[3] N. Andarwulan. R. Batari. D.A. Sandrasari. B. Bolling. H. Wijaya, "Flavonoid Content and Antioxidant Activity Of Vegetables from Indonesia". Journal Food Chem, 121, 2010

[4] Faridatussadah, Siti, "Isolasi dan identifikasi Senyawa Flavonoid dari Daun Mangkok (Polyscias scuttellarium (Burm.f.) Fosb)", Jurnal Farmasi, vol 2 (1), 2016

[5] F. Juliantina. D.A. Citra. B. Nirwani. T. Nurmasitoh. E.T. Bowo, "Bakterial Terhadap Bakteri Gram Positif dan Gram Negatif", Jurnal Kedokteran dan Kesehatan Indonesi, vol 1 (1): 1-10, 2009

[6] Radii, M., Buku Ajar Mikrobiologi Panduan Mahasiswa Farmasi dan Kedokteran. Jakarta: Penerbit Buku Kedokteran EGC: 127, 2011

[7] Jawetz, E, J. L. Melnick, E. A. Adelberg, G. F. Brooks, J. S. Butel, dan L. N. Ornston. Mikrobiologi Kedokteran. Edisi ke- 20. Terjemahan oleh Nugroho \& R. F. Maulany. Jakarta: Penerbit Buku 
Kedokteran EGC, 1995

[8] Andriyani, D., Utami, P I., Dhiani, B A. Penetapan Kadar Tanin Daun Rambutan (Nephelium lappaceum. L) Secara Spektrofotometri Ultraviolet Visibel, Journal Pharmacy, vol 07 (02): $1-11,2010$
[9] Lully Hanni, Farmakognosi dan Fitokimia, $7^{\text {st }}$ ed, Jakarta: SDM Kesehatan, 2016

[10] Muharni, Fitrya, Sofa, F., Uji Aktivitas Antibakteri Ekstrak Etanol Tanaman Obat Suku Musi di Kabupaten Musi Banyuasin Sumatera Selatan, Jurnal Kefarmasian Indonesia, vol. 7 No.2, 2016 